

Contents List available at VOLKSON PRESS

Economics \& Management Innovations(EMI)

DOI : http://doi.org/10.26480/icemi.01.2017.59.60

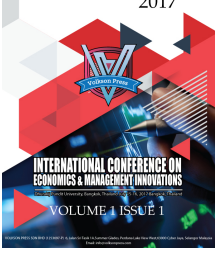

\title{
Analysis on the phenomenon of falsely making out vat invoices for agricultural products
}

\author{
Cui Shufen ${ }^{1, a}$,SunLiHeng ${ }^{2, b}$, \\ 12 Wuhan Donghu University, Wuhan, Hubei, P.R.China Email: ${ }^{\mathrm{a}} 471101875 @ q q . c o m,{ }^{\mathrm{b}}$ 790124653@qq.com
}

This is an open access article distributed under the Creative Commons Attribution License, which permits unrestricted use, distribution, and reproduction in any medium, provided the original work is properly cited.

\section{ARTICLE DETAILS}

\section{Article History:}

Received 02 october 2017

Accepted 06 october 2017

Available online 11 october 2017

\section{ABSTRACT}

In view of the restraining factors of the actual effect of vat reform, this paper analyzes the phenomenon of falsely making out vat invoices in agricultural products e-commerce, and puts forward the influence and countermeasures on the development of agricultural enterprises from the aspects of policy.

\begin{tabular}{l} 
Keywords: \\
Electronic commerce of \\
agricultural products, Falsely \\
making out vat invoices \\
\hline
\end{tabular}

\section{Analysis of invoices for electronic commerce of agricultural products}

Agricultural products industry chain in China, especially the operators of ecommerce enterprises, most of the small-scale operations, financial accounting irregularities, do not have the general taxpayer conditions. Internet plus model is the main way for many enterprises to improve their profit pattern. Logistics is the weak environment of internet economic engine, high logistics cost is the biggest obstacle to regional economic development, because the logistics cost is an important part of enterprise operating cost, sometimes the proportion is very high, the speed and cost of logistics become an important node of direct competition, and it is difficult to construct the key of enterprise profit model. In order to reduce the cost and improve the efficiency of capital operation, the middleman or agent will transport the goods directly from the upstream suppliers to the buyers, and never enter their warehouses Some small business stores, the stage of entrepreneurship is not at all, is completely zero inventory operation, according to the order to direct the goods from the factory to the consumers.

\section{1 policy business and the dilemma of making out vat}

This is an there is no business transaction, but it belongs to the " A New Beginning" behavior of vat collection and management, and belongs to the special invoice of " falsely making vat ". The accusation is not small, enterprises are not only difficult to profit in the case of profit, but also difficult to apply for general taxpayer, and face serious criminal punishment. For the tax authorities, the enterprise management tripartite repay a debt, closing, the company unified payment situation of a large number of cases, strict check of manpower shortage, high cost, basic do not have operability. The parties are in a dilemma. For example, the rapid loss of fresh products, management is simple and convenient, combined with low profit, business must be accompanied by the city, if not according to market flexible operation, is unable to survive, to achieve " the integration of integration" is no different from the fantasy.

The current tax law enforcement agencies forced " A New Beginning ", smallscale taxpayers in the general taxpayer services to provide a tax credit link, there is a legal obstacle: their own invoicing does not go to the law, this dilemma not only not conducive to small-scale operation of taxpayers' normal production and operation, but also violates the principle of tax equity. The agricultural products e-commerce enterprises have the dilemma of economic development and "law-abiding ";
代 invoice and " A New Beginning" crime has become an important factor restricting the development of the industry.

Farmers can be said to be in a situation without knowing the law, although the tax authorities have stringent process control regulations, the actual implementation cannot be implemented. And the

industry and small business can be executed, can escape, if the cat and mouse game, a large amount of administrative cost is wasted in the investigation. Because the law is difficult to blame, it unavoidably produces selective law enforcement and the right rent-seeking.

\subsection{Excessive sentencing of falsely making out value-added tax} invoices

The judicial interpretation of the legislative value added tax is stipulated in the 90's, the political and social economic culture has undergone earthshaking changes, in which the original law stipulates the amount of sentencing is low, the heavy standard is low, easy to cause the judicial to make small amount, the crime is fast, the punishment is too heavy, the frequency of occurrence is high, the punishment capping is early and so on And " falsely making out the special invoices for value-added tax" is a term of 10 years' imprisonment and life imprisonment, far higher than the punishment stipulated in the tax evasion ( "tax evasion" is 3 to 7 years' imprisonment ). And the small scale taxpayers as a last resort, " third rate ", it is easy to reach the maximum penalty standard, if all punishment, is obviously too heavy.

In order to enhance the judicial flexibility, the criminal law ( 1997 ) adopts the general crime amount model to make out false conviction standards: " large amount or other serious circumstances, huge amount or other special serious circumstances ", China has a vast territory, the east and west economic development level difference is large, the understanding of the amount difference is also large, lack of clarity, difficult to accurately determine sentencing, difficult to guarantee judicial fair and fair. For example: make out 1 million yuan, and may face the same punishment similar to the same, in the same risk, the same amount of criminals will choose a higher number of 5 million. As a result, the number of falsely making out is increasing, big to surprising, but not necessarily facing heavier punishment.

The taxpayer's legal compliance costs are too large. With the social and economic environment has been earth-shaking changes, the law making environment changes larger, the relevant provisions are not revised in time, 
seriously lagging behind the reality. Causing the taxpayer to comply with the cost is huge, compliance cost is too large if the enterprise can not profit, will take the risk, willing to take the risk of illegal, but also there is escape from the fluke mind.

The taxpayer's legal compliance costs are too large. With the social and economic environment has been earth-shaking changes, the law making environment changes larger, the relevant provisions are not revised in time, seriously lagging behind the reality. Causing the taxpayer to comply with the cost is huge, compliance cost is too large if the enterprise can not profit, will take the risk, willing to take the risk of illegal, but also there is escape from the fluke mind.

2. On the suggestion of making out the sentencing of value-added tax invoices

\subsection{Perfecting the legislation on the crime of making out special invoices for value-added tax}

Based on the national conditions, set up the tax coordination mechanism to promote economic development objectives, respect the private autonomy of the trading subjects, and timely comb and improve relevant legal provisions to promote the release of business tax to promote economic development positive effects.

\section{2 "keep pace with the times" and put forward supporting explanations as soon as possible}

China's regional economic development is not balanced, the relevant laws are not perfect, should be given the power of judicial interpretation of the judicial organs of different regions, and unified the determination of the amount of the crime of special invoices for value-added tax, unified, standard determination methods, and timely adjustment according to the economic development situation.

\section{3 promoting the social perfection of the crime of making out the special invoices for falsely making out value-added tax}

The causes of falsely making out special vat invoices are complex, except for the obvious behavior of intentional crimes, the behavior of Fei illegal acts should be analyzed concretely, and the taxpayer can enjoy the economic effect of tax reduction policy and avoid illegal traps. Should make the tax law mode of value added tax more flexible and adapt to the need of the development of our market economy, divide the tax subject reasonably, lest damage the enthusiasm of small and medium-sized enterprises.
At the same time, the adaptation of the law should be fully taken into account in the revision and perfection of the law. In particular, we should fully absorb the opinion of the tax compliance, measure the cost of compliance, and the operability of the implementation, so that the positive effect of the relevant tax reform can be realized, and really play the role of promoting economic development.

\section{Conclusion}

Although the business tax value-added tax has the function of reducing burden, but due to the specific enforcement system, such as the compulsory provisions of A New Beginning combination, it is difficult for enterprises to enjoy the relevant tax preferential policies. At the same time, it is urgent and important to adjust the relevant policies and laws to promote the development of agricultural e-commerce enterprises.

\section{References}

[1] Cui Shufen, Sun Liheng. Influence of "The Business Tax to VAT Transformation Refor $m$ " on Enterprise Tax Burden and Financial Countermeasures [J]. Finance and Accounti ng Monthly.2014(09).

[2] XieWangyuan, GuoLifeng. Study on the Crime of Falsely Making out Special Invoices for VAT [J]. Shandong Justice.2002(5): 9.

[3] The Second Criminal Panel of High People' s Court of Shangdong Province. Study on the Amount of Economic Crime and Measurement Of Penalty [J]. Shandong Justice. 2006(4) : 31

[4] Liang Jian. Study on Falsely Making out Special Invoices for VAT [J] Journal of University of Science and Technology Beijing (Social Sciences Edition).2003(1) : 34

[5] Leng Ling, Li Na. Legal Application of the Crime of Falsely Making out Special Invoices for VAT [J]. Forward Position.2012(02)

[6] Du Wei. Theory of Over-punishment on the Crime of Falsely Making Out Specialized Value Added Tax Receipts[N]. Journal of Southwest University of Political Science and Law.2015(01)

[7] Cui Shufen, Wang Yepeng. Hu Cheng. Research on New Agricultural Management System and Agricultural Management Mode Under the Background of Electricity Supplier. Logistics Engineering and Management. 2015(01)

Label : Chinese annotation of the project proposed in 2015: " this study is supported by the cooperative innovation center of Hubei province, Wuhan east lake college, Wuhan ( breeding ) ( Wu east hospital research [ No. 11] 